\title{
Analysis of the genetic diversity of the coastal and island endangered plant species Elaeagnus macrophylla via conserved DNA-derived polymorphism marker
}

\author{
Yi Wang ${ }^{\text {Equal first author, 1 }}$, Yan Ma ${ }^{\text {Equal first author, } 1}$, Bingyu Jia ${ }^{1}$, Qichao Wu ${ }^{1}$, Dekui Zang ${ }^{\text {Corresp., } 1}$, Xiaoyan Yu ${ }^{1}$ \\ ${ }^{1}$ College of Forestry, Key Laboratory of State Forestry Administration for Silviculture of the Lower Yellow River, Shandong Agricultural University, Tai'an, \\ Shandong province, China \\ Corresponding Author: Dekui Zang \\ Email address: zangdk@sdau.edu.cn
}

The genetic diversity and genetic structure of five natural populations of the island and coastal endangered plant species Elaeagnus macrophylla were analyzed via conserved DNA-derived polymorphism molecular markers. A total of 289 discernible loci were obtained from 102 individuals via fifteen primers, and $100 \%$ of the loci were polymorphic. The observed number of alleles was 1.9654, and the effective number of alleles was 1.2604. Nei's genetic diversity index was 0.1724 on average, and Shannon's information index was 0.2869 , indicating that Elaeagnus macrophylla had lower levels of genetic diversity than those reported for its continental relatives and other continental species. The average percentage of polymorphic loci was $42.1 \%$, and the maximum and minimum were $80.97 \%$ and $14.88 \%$, respectively, which were associated with the Nanji Island and Liugong Island populations, respectively. The populations of Elaeagnus macrophylla were highly differentiated. Cluster analysis revealed that the similarity between the tested samples was related to their geographical location, that the samples from the same island tended to cluster together, and that there was no cross-clustering between samples. The Nanji Island and Da Rushan populations differentiated into two subpopulations. Last, we detected no correlation between genetic distance and geographic distance between populations (Pearson's correlation coefficient $r=0.256579$, $p$-value $=0.8309$ ). 


\section{Analysis of the genetic diversity of the coastal and} island endangered plant species Elaeagnus macrophylla via conserved DNA-derived 5 polymorphism markers

Yi Wang ${ }^{1}$ Yan $\mathrm{Ma}^{1} \quad$ Bingyu Jia $^{1} \quad$ Qichao $\mathrm{Wu}^{1} \quad$ Dekui Zang $^{1} \quad$ Xiaoyan $\mathrm{Yu}^{1}$

${ }^{1}$ College of Forestry, Shandong Agricultural University, Key Laboratory of State Forestry Administration for Silviculture of the Lower Yellow River, Tai'an, Shandong, China

Yi Wang and Yan Ma contributed equally to this work.

Corresponding Author:

Dekui Zang ${ }^{1}$

No. 61 Daizong Street, Shandong Agricultural University, Tai'an, Shandong, 271000, China

Email address: zangdk@sdau.edu.cn

\section{Abstract}

The genetic diversity and genetic structure of five natural populations of the island and coastal endangered plant species Elaeagnus macrophylla were analyzed via conserved DNA-derived polymorphism molecular markers. A total of 289 discernible loci were obtained from 102 individuals via fifteen primers, and $100 \%$ of the loci were polymorphic. The observed number of alleles was 1.9654 , and the effective number of alleles was 1.2604. Nei's genetic diversity index was 0.1724 on average, and Shannon's information index was 0.2869 , indicating that Elaeagnus macrophylla had lower levels of genetic diversity than those reported for its continental relatives and other continental species. The average percentage of polymorphic loci was $42.1 \%$, and the maximum and minimum were $80.97 \%$ and $14.88 \%$, respectively, which were associated with the Nanji Island and Liugong Island populations, respectively. The populations of Elaeagnus macrophylla were highly differentiated. Cluster analysis revealed that the similarity between the tested samples was related to their geographical location, that the samples from the same island tended to cluster together, and that there was no cross-clustering between samples. The Nanji Island and Da Rushan populations differentiated into two subpopulations. Last, we detected no 
34

35

36

\section{Introduction}

38

39

40

41

42

43

44

45

46

47

48

49

50

51

52

53

54

55

56

57

58

59

60

61

62

63

64

65

66

67

68

69

70

71

72

correlation between genetic distance and geographic distance between populations (Pearson's correlation coefficient $r=0.256579$, $p$-value $=0.8309$ ).

Elaeagnus macrophylla is an endangered evergreen shrub species of East Asian coastal areas and islands. It is distributed in the Shandong, Zhejiang, and Jiangsu Provinces of China, mainly on offshore islands and in coastal lowlands (Chinese Flora, 1983). Owing to its unique geographical distribution pattern, E. macrophylla is highly valuable for studying coastal flora and can be widely used in coastal greening because of its tolerance to sea breeze, salinity, drought, and poor soil (Zang, 2016). This species also has potential economic value; for example, it can be used for the production of fruit juice and wine (Zang, 2016). In recent years, with the rapid development of the economy and coastline, intensification of human interference, and continuous reduction in suitable environments, the number, and size of natural populations have decreased sharply, causing this species to become endangered.

The genetic diversity of island species is generally lower than that of continental species, the risk of extinction is greater for the former (Raven, 1998). From the 17th century to the 20th century, 384 species of vascular plants went extinct worldwide, 139 of which were island plant species. Moreover, forty percent of vulnerable or endangered vascular plant species are island species (Reid \& Miller, 1989). Human disturbances, such as habitat destruction and invasion by alien species, are considered to be the main factors threatening island species (Wolf \& Harrison, 2001). Studies of Ilex integra based on inter simple sequence repeat (ISSR) molecular markers (Leng et al., 2005) and Neolitsea sericea based on random amplified polymorphic DNA (RAPD) molecular markers (Wang et al., 2004) showed that the geographical isolation of islands had a significant effect on the genetic differentiation of island populations and that the genetic diversity of island relatives was lower than that of close continental relatives. However, no studies of the genetic diversity of the island plant species E. macrophylla have been conducted.

The conserved DNA-derived polymorphism (CDDP) method is based on a single primer amplification reaction, with primers designed to target conserved sequences of plant functional genes, mostly transcription factors such as WRKYs, MYBs, MADs, ERFs, KNOXs, and ABP1. Because of the strong conservation of some sequences of plant DNA, CDDP molecular marker technology can be used across different species. Studies of rice (Oryza sativa) have shown that CDDP markers have many advantages, including convenience, low cost, and rich polymorphism, and can effectively mark sequences of target traits (Collard \& Mackill, 2009). Compared with traditional DNA molecular methods, the CDDP method is practical because the primers used in CDDP are specific for conserved gene sequences. By amplifying these conserved sequences, which tend to be linked to phenotypic traits, CDDP markers can provide advantages for plant genetic diversity assessment (Andersen \& Lübberstedt, 2003). Since Poczai first successfully used CDDP markers and within-target markers to investigate the genetic diversity and group structure of Solanum dulcamara (Poczai et al., 2011), CDDP markers have proven useful in the 
73

74

75

76

77

78

79

80

81

82

83

84

85

86

87

88

89

90

91

92

93

94

95

96

97

98

99

100

101

102

103

104

105

106

107

108

109

110

111

analysis of several other plant species, such as Chrysanthemum (Li et al., 2014), Paeonia suffruticosa (Li et al., 2013), Vaccinium vitis-idaea (Fang et al., 2016), and Rosa rugosa (Jiang \& Zang, 2018). However, CDDP markers have not yet been used to study E. macrophylla.

In this study, CDDP markers were used to analyze the genetic diversity and genetic relationships between major natural populations of E. macrophylla in China, with the aim of revealing the level of genetic diversity and degree of genetic differentiation, assessing the relationships between populations, examining the influence of geographical isolation and human factors on the genetic structure, and providing a scientific basis for the protection and rational utilization of E. macrophylla.

\section{Materials and Methods}

\section{Plant materials}

A total of 102 individual leaf samples were collected from 7 islands and offshore sites (Fig. 1 and Table 1) from April to July 2018; sampling was conducted within the natural distribution area of E. macrophylla. Interval sampling was applied except within small populations (such as the Liugong Island population, where samples from all individual plants found were collected). Only one individual each was found on Lingshan Island and Putuo Island. After the samples were collected, silica gel was used to quickly dry the specimens, after which they were stored at $20^{\circ} \mathrm{C}$.

\section{DNA extraction and PCR amplification}

Total DNA was extracted from E. macrophylla via the modified cetyltrimethylammonium bromide (CTAB) method (Doyle \& Doyle, 1987). The quality and purity of DNA were determined by $2 \%$ agarose gel electrophoresis, and a spectrophotometer (Thermo Fisher Scientific Inc., USA) was used to ensure DNA quantification. All DNA samples were stored at $20^{\circ} \mathrm{C}$ for later use.

The DNA from one sample per population was selected to screen 21 CDDP primers (Collard \& Mackill, 2009) (synthesized by Sangon Biotech, China). The results revealed 15 primers with clear and reproducible amplification bands were screened out (Table 2). PCR was conducted in a total reaction volume of $20 \mu \mathrm{l}$ consisting of $10 \mu \mathrm{l}$ of $2 \times$ Ex Taq MasterMix (dye), $7.5 \mu 1$ of double-distilled $\mathrm{H}_{2} \mathrm{O}, 1 \mu \mathrm{l}$ of $30 \mathrm{ng} / \mu \mathrm{l}$ DNA template, and $1.0 \mu \mathrm{l}$ of $10 \mathrm{pmol} / \mu \mathrm{l}$ primers (Sangon Biotech, China). A standard PCR thermocycler (RT-PCR 7500, Thermo Fisher Scientific Inc., USA) was used and the PCR program was as follows: an initial denaturation step at $94^{\circ} \mathrm{C}$ for 3 min; 35 annealing cycles of $94^{\circ} \mathrm{C}$ for $1 \mathrm{~min}, 50^{\circ} \mathrm{C}$ for $1 \mathrm{~min}$ and $72^{\circ} \mathrm{C}$ for $2 \mathrm{~min}$; and a final extension of $72^{\circ} \mathrm{C}$ for $5 \mathrm{~min}$. The PCR products were subsequently stored at $4{ }^{\circ} \mathrm{C}$. The products were then electrophoresed on a $2 \%$ agarose gel (110 V and $110 \mathrm{~mA})$ for $1.5-2 \mathrm{~h}$; a DL2000 
112 marker was used as a size marker. The electrophoresis results were imaged and recorded by a gel

113 imaging system. All amplification procedures were repeated at least twice to ensure the

114 repeatability of the experiment.

115

116

117

118

119

120

121

122

123

124

125

126

127

128

129

130

131

132

133

134

135

136

137

138

139

140

141

142

143

144

145

146

147

148

149

\section{Statistics and data analysis}

We used POPGEN v.1.32 (Yeh, Yang \& Boyle, 1999) to compute the following parameters: observed allele number $(\mathrm{Na})$, effective allele number $(\mathrm{Ne})$, Nei's genetic diversity index $(\mathrm{H})$, Shannon's information index (I), polymorphic loci, percentage of polymorphic loci (PPL, \%), total genetic diversity $(\mathrm{Ht})$, genetic diversity within populations (Hs), the genetic differentiation coefficient (Gst) and gene flow ( $\mathrm{Nm}$ ) between populations. Estimates were also calculated within sampling localities when significant differences among specimens were detected.

A dendrogram was generated by the unweighted pair group method with arithmetic mean (UPGMA) clustering procedure in NTSYS-pc 2.10e software (RohlF, 1994). The relationship between geographic distance and genetic distance was analyzed with Pearson's correlation coefficients in R.

The genetic structure of populations was further assessed via the Bayesian clustering approach implemented in STRUCTURE v.2.3.4 (Pritchard, Stephens \& Donnelly, 2000). The number of potential genetic clusters (K values) was set from 1 to 10 , with 10 independent runs for each $\mathrm{K}$. The contribution of the accessions to the genotypes was calculated on the basis of a $10^{5}$ iteration burn-in period and $10^{5}$ iteration sampling period. The optimal number of $\mathrm{K}$ clusters was then identified according to the methods of Evanno, Regnaut \& Goudet (2005).

\section{Results and Analysis}

\section{Population- and species-level diversity of E. macrophylla}

The DNA of 102 samples was amplified with 15 primers, yielding 289 bands, and the fragment length was between 500 and $2000 \mathrm{bp}$ (Fig. 2). The number of amplified bands ranged from 11 to 30 , and the average number of amplified bands was 19.3. The number of Pr2 and Pr6 amplification bands was the highest, at 30, and the number of $\operatorname{Pr} 7$ and $\operatorname{Pr} 8$ amplification bands was the lowest, at 11 . The percentage of polymorphisms reached 100\% (Table 2), which indicated that the genomic DNA polymorphism of E. macrophylla was high.

At the population level, the PPL ranged from $14.88 \%$ to $80.28 \%$, with an average of $48.928 \%$, whereas it was $96.54 \%$ at the species level. The Na ranged from 1.1488 to 1.8028 , while the Ne varied from 1.0739 to 1.2410 . $\mathrm{H}$ varied from 0.0446 to 0.1580 , with an average of 0.1149 , and I ranged from 0.0690 to 0.2613 , with an average of 0.1848 . At the species level, $\mathrm{H}$ and I were 0.1724 and 0.2869 , respectively (Table 3 ). The Na, Ne, H, I, and PPL were consistent among 
150 populations, with the NJD population presenting the largest values and the LGD population

151

152

153

154

155

156

157

158

159

160

161

162

163

164

165

166

167

168

169

170

171

172

173

174

175

176

177

178

179

180

181

182

183

184

185

186

187

188

189

190

191

192

193

194

presenting the lowest values, all of which were lower than those at the species level.

\section{Genetic differentiation of the populations of E. macrophylla}

The Ht and Hs were 0.1706 and 0.1149, respectively, as calculated by POPGEN v.1.32 software. The Gst was 0.3263 , indicating that $67.37 \%$ of the variation was within the populations and that $32.63 \%$ of the variation occurred between the populations. A certain degree of genetic differentiation was observed between the populations. The $\mathrm{Nm}$ was 1.0325 , indicating that there was some (albeit limited) genetic exchange between populations.

Genetic differentiation between populations can be further analyzed on the basis of Nei's genetic distance and genetic identity. For the five populations of E. macrophylla, the genetic distance was between 0.0490 and 0.1443 (Table 4), with a mean of 0.08127 , and Nei's genetic identity was between 0.8656 and 0.9588 , with a mean of 0.9226 .

\section{UPGMA cluster analysis}

The applied measure of genetic similarity was used to construct UPGMA dendrograms (Fig. 3). The clustering map showed that the five populations could be divided into three groups. One group represented the LGD population. The DRS, NJD, and LS populations formed a second group, indicating that these three populations are closely related, the third group represented the DGD population. Populations with similar geographical distances were not clustered into the same group, indicating that the genetic distance between the populations of E. macrophylla was not related to geographical distance. Consistent with these results, the Pearson correlation coefficient test revealed no significant correlation between geographic and genetic distance (Pearson's correlation coefficient $r=0.256579$, $p$-value $=0.8309$ ).

The UPGMA clustering map provided a clear division of the 102 samples (Fig. 4). Notably, cross-clustering occurred between samples from different populations, and samples from the same island tended to cluster together. The groups in the clustering results were generally consistent with the regional sources of the samples. As clearly shown by the clustering map, all the samples from the LGD population formed a small branch and then formed another branch with all the samples from the DRS population. Among the samples, Nos. 9-18 from the DRS population were more closely related to the samples from the LGD population than to Nos. 19-28 from the DRS population; thus, differentiation within the DRS population was observed between Nos. 9-18 and Nos. 19-28. All samples from the LS population formed a group, all samples from the DGD population formed another group, and the two groups formed a large branch. One sample from PTD formed a separate group. Samples from the NJD population were composed of two subpopulations. On the basis of the sampling location and latitude and longitude, samples 29-40 were collected in the northwestern part of NJD (121 $\left.{ }^{\circ} 3^{\prime} 24-121^{\circ} 3^{\prime} 8,27^{\circ} 27^{\prime} 53-27^{\circ} 28^{\prime} 21\right)$, and samples 41-61 were collected in the southeastern part of NJD (121 ${ }^{\circ} 5^{\prime} 52-121^{\circ} 6^{\prime} 11,2^{\circ} 26^{\prime} 54-$ $27^{\circ} 27^{\prime} 12$ ). Twenty-one samples (Nos. 41-61) formed a group, 12 samples (Nos. 29-40) formed another group, and these two groups formed different branches. Therefore, the samples could be easily divided into 5 groups on the basis of the clustering results.

\section{Population structure analysis}


195

196

197

198

199

200

201

202

203

204

205

206

207

208

209

210

211

212

213

214

215

216

217

218

219

220

221

222

223

224

225

226

227

228

229

230

231

232

233

234

235

236

237

238

The results of the Bayesian clustering analysis of the genetic structure showed that the populations of $E$. macrophylla best fit three genetic groups, and when $\mathrm{K}=5$, the delta $\mathrm{K}$ value was also large (Fig. 5A). When $\mathrm{K}=3$ (Fig. 5B), the LGD population and half of the DRS samples clustered into the first groups, further indicating that the two populations were closely related. Most samples from the LS population, half of the samples from the DRS population and all the samples from the NJD population clustered into the second group, and a portion of the samples from the LS and DGD populations formed the third group. When $\mathrm{K}=5$ (Fig. 5C), the LGD population and half of the DRS samples clustered into the first group, half of the DRS samples and the NJD samples indicated in yellow in the figure clustered into the second group, the NJD samples indicated in blue in the figure formed the third group, all samples from the LS population clustered into the fourth group, and all samples from the DGD population clustered into the fifth group. The LGD, LS, and DGD population pedigrees were simple, and the samples from the islands tended to cluster together. However, the NJD and DRS populations were different. The NJD population formed two subpopulations when $\mathrm{K}=5$ : a northwestern group (indicated in yellow) and a southeastern group (indicated in blue). The DRS population differentiated into two subpopulations when $\mathrm{K}=3$ and $\mathrm{K}=5$ : Nos. 9-18 and Nos. 19-28, respectively.

\section{Gst and Nm of the two NJD and DRS subpopulations}

The Nm between the NJD and DRS subpopulations was 2.6084 and 2.0843, respectively, the Gst was 0.1609 and 0.1935 , respectively. The subpopulations presented strong gene flow but high genetic differentiation.

\section{Discussion}

Frankham (1997) compared and analyzed the allelic diversity of 202 groups of land and island populations of various species, including those of mammals, birds, fish, reptiles, insects, and plants: in 165 cases $(81.7 \%)$, the genetic diversity of island populations was lower than that of continental populations, with an average decrease of $29 \%$. The average PPL via the CDDP markers in five populations of the island plant species E. macrophylla was $48.928 \%$, the Ne was 1.1801, $\mathrm{H}$ was 0.1149 , and I was 0.1848 . All these numbers are far below those of populations of the continental species Camellia japonica $(\mathrm{PPL}=86.11 \%, \mathrm{Ne}=1.4775, \mathrm{H}=0.2940, \mathrm{I}=0.4459)$ (Juan, 2018) and Paeonia suffruticosa (PPL=72.1\%, Ne=1.2389, H=0.1623, I=0.2682) (Li, 2013) estimated on the basis of CDDP marker data. Moreover, compared with the rich genetic diversity of another species within the same genus (Elaeagnus mollis) (Qin, Zhang \& Yan, 2006), the genetic diversity of E. macrophylla is low, which is consistent with the results of Frankham. As an endangered coastal plant species, E. macrophylla has a lower genetic diversity than its continental relatives and other continental species have. For island species, breeding characteristics, dispersal capability, and effective population size are often considered important factors affecting genetic diversity (Frankham, 1997; Weller, Sakai \& Straub, 1996). E. macrophylla is a typical bisexual flowering plant species that produces flowers that have a small diameter and that produce nectar; thus, this species relies mainly on small insects as pollinators for cross-pollination (Zang, 2012). The Ht of E. macrophylla was lower than the average value

Peer] reviewing PDF | (2019:06:38915:6:3:NEW 21 Dec 2019) 
239 of insect-pollinated plants $(\mathrm{Ht}=0.2019$; Hanwick \& Godt, 1990), indicating that its insect-borne 240 pollination has been affected to some extent. Owing to the large sea breeze on the island, insects 241 can live only in groups, which affects their range of activities. As a result, pollen transmission is 242 limited to a very small range, and random fixation of alleles and limited gene exchange leads to 243 poor population expansion, thus reducing genetic diversity (Hamrick \& Nason, 1996; Hamilton $244 \&$ Miller, 2002). As another important carrier of gene flow, seeds are also essential for the 245 natural regeneration and expansion of plant populations and for increasing their genetic diversity 246

\section{(Hamilton \& Miller, 2002). According to previous studies, E. macrophylla can produce fruit} naturally in the wild, and the fruit is sweet (Zang, 2016). The fruit is heavily favored by birds, and some birds that feed on these fruits can spread the seeds. Unfortunately, owing to the influence of insect pollination, the seed setting rate in the wild is low. Moreover, owing to increased amounts of human activities, especially the vigorous development of tourism, island birds are becoming increasingly rare, which further restricts the spread of seeds and affects the genetic diversity of populations. Compared with that of C. japonica and E. mollis, the distribution of populations of E. macrophylla, an island species, is small. E. macrophylla occupies a fragile habitat and has a narrow distribution range, making it more vulnerable than continental species to extinction (Francisco-Ortega et al., 2000). Island segregation means fragmentation of habitats, which leads to the maintenance of small populations in fragmented habitats; as such, genetic diversity of endangered species may be lost because genetic drift causes allele loss and because inbreeding frequencies are increasing (Zhang \& Jiang, 1999; Emerson, 2002).

In the present study, the $\mathrm{Ht}$ and $\mathrm{Hs}$ of E. macrophylla were 0.1706 and 0.1149 , respectively. Compared with endangered and Chinese secondary protected plants (Fu \& Jin, 1992), including R. rugosa, in previous CDDP-based ( $\mathrm{Ht}=0.2770, \mathrm{Hs}=0.1522)$ studies (Jiang \& Zang, 2018), $E$. macrophylla in the present study showed low diversity. Similarly, the diversity values in the present study were lower than those estimated via CDDP markers for the plant species C. japonica $(\mathrm{Ht}=0.2874, \mathrm{Hs}=0.2518$; Juan, 2018). Gst is calculated as the ratio of betweenpopulation genetic variance to the total variance among populations (Wright, 1965). The Gst of the five populations of E. macrophylla was 0.3263 , indicating that $32.63 \%$ of the variation existed among the populations. Genetic differentiation of the E. macrophylla populations was significant on the basis of Nei's Gst classification criteria for genetic differentiation (low, Gst $<$ 0.05 ; medium, Gst $=0.05 \sim 0.15$; and high, Gst $>0.15)(\mathrm{Nei}, 1978)$. This genetic differentiation value was greater than the average value of 23 species $(28.06 \%)$ of the Carina Islands (Francisco-Ortega et al., 2000). Furthermore, the genetic differentiation between E. macrophylla populations was relatively high, and the prevention of gene flow, genetic drift, and inbreeding was the main cause of genetic differentiation among populations (Starkin, 1987; Ouborg, Piquot \& Groenendael, 1999; Manel, 2003).

$\mathrm{Nm}$ refers to the process by which a biological individual disperses from its place of origin, followed by the exchange of genes between populations. Such exchange may occur between biological populations of the same species or between different species and is essential to the evolution of many plant populations (Grant, 1991; Gerber et al., 2014). The populations of $E$. macrophylla displayed little gene flow ( $\mathrm{Nm}=1.0325)$, and the UPGMA clustering analysis of samples revealed no hybridization among individuals from different localities. Structure analysis $(\mathrm{K}=5)$ revealed that most of the populations had a simple pedigree, and the genetic exchange between each pair of populations was low. These results were mainly due to the geographical isolation of the islands (mainly barriers posed by seawater), which limited the range of dispersal

Peer] reviewing PDF | (2019:06:38915:6:3:NEW 21 Dec 2019) 
285 by pollen- and seed-dispersing birds (Kwon \& Morden, 2002). For the E. macrophylla

286 populations, the shortest distance is between the populations of LS and DGD $(8100 \mathrm{~m})$; it is

287 difficult for small pollinators to spread pollen across islands separated by vast seas. In addition to

288 pollen, seeds play an important role in the spread of gene flow. One important aspect of seed

289 movement is its role in the initial founding of a population (Chung, Chung \& Oh, 2002). In a

290 study of $N$. sericea, owing to seeds being dispersed over long distances by birds, numerous

291 seedlings and juveniles (mostly aged $<5 \mathrm{yr}$ ) of $N$. sericea were dispersed within a range of

292 approximately $480 \mathrm{~m}$ (Hakdongri on Keojae Island) and $680 \mathrm{~m}$ (Naechori on Oenaro Island),

293 respectively, from their maternal plants (Chung, Chung \& Oh, 2002). The fruit of $E$.

294 macrophylla is a drupe-shaped nut with a seed and rich flesh (Zang, 2012). After birds feed and

295 digest their food, they can excrete seeds in their feces. This type of transmission is called intra-

296 animal transmission, which carries seeds far away and promotes gene exchange (Petit et al.,

297 2003). It is difficult to directly observe how far birds can spread seeds in the wild, but the

298 retention time of seeds in the digestive tract of fruit-eating birds can be used to determine the

299 potential propagation distance and the ability to reach the appropriate breeding ground (Manson

$300 \&$ Stiles, 1998). The retention time of fruits of Sorbus pohuashanensis in the digestive tract of

301 birds were found to be approximately $20 \mathrm{~min}$. The first stopping point after feeding was mostly

302 located between 5 and $10 \mathrm{~m}$ from the female plants, but the birds could have had many various

303 landing points within $20 \mathrm{~min}$, which might spread the seeds to distant areas (Zhang et al., 2010).

304 However, birds are affected by factors such as seed size, feed intake, digestion, and excretion;

305 thus, it is very difficult to distribute seeds between distances over sea areas greater than $8000 \mathrm{~m}$

306 or farther. Last, water currents are also a major medium of genetic exchange between islands

307 (Kwon \& Morden, 2002). Zhang et al. (2007) studied the differences in genetic variation

308 between the species E. emarginata, I. integra and Machilus thunbergii. Clustering analysis

309 revealed that the reason for the intermixing of individuals among E. emarginata populations was

310 that seeds floating with ocean currents promoted gene exchange among populations, while those

311 of I. integra and $M$. thunbergii did not. Therefore, the genetic differentiation of E. emarginata is

312 lower than that of I. integra and M. thunbergii. The fruits of E. macrophylla fall into the sea

313 because of sea breezes, but the spread of seeds by ocean currents to allow genetic exchange

314 between populations is a rare event, as submersion quickly reduces the germination capability

315 after a few days (Angélique \& Debussche, 2000). When soaked in seawater, seeds of I. integra

316 also presented a germination rate close to zero (Leng et al., 2005). Our sample clustering map

317 revealed no hybridization among individuals, indicating that the genetic exchange between the

318 populations is limited. Therefore, it is very difficult for E. macrophylla to achieve genetic

319 exchange via seeds floating by currents. For E. emarginata, the reason for success may be that

320 the distance between the islands is short and the seeds do not lose their ability to germinate after

321 floating.

322 The results of the Bayesian clustering analysis showed, that when $K=3$, the same gene pool

323 exists between different populations. On the basis of limited gene flow and high genetic

324 differentiation between populations, we speculate that the reason for this may be that $E$.

325 macrophylla inherits the gene pool of its ancestors, such that populations with distant geographic

326 distances also are part of the same gene pool.

327 As opposed to the high genetic differentiation between different island populations,

328 individuals on islands are often grouped into a single group, indicating that individuals in each

329 population have relatively close kinship, which may be related to the small island range, similar

330 habitats within the population, and strong gene flow (Sahuquillo \& Lumaret, 1995; Carlos, 
331 Emerson \& Oromi, 2000); however, the DRS and NJD populations are exceptions. According to

332 the UPGMA clustering and STRUCTURE analysis results, the DRS population differentiated

333

334

335

336

337

338

339

340

341

342

343

344

345

346

347

348

349

350

351

352

353

354

355

356

357

358

359

360

361

362

363

364

365

366

367

368

369

370

371

372

373

374

375

376

into two subpopulations: Nos. 9-18 and Nos. 19-28. Gene flow $(\mathrm{Nm}=2.0843)$ was strong between the two subpopulations, but there was high genetic differentiation $(\mathrm{Gst}=0.1935)$.

Because gene flow was not blocked and the habitats were similar, we speculate that the cause of this result was that the DRS population contains two gene pools, and complete gene introgression has not yet occurred in the two subpopulations under the condition of a gene flow of 2.0843. When $\mathrm{K}=3$, the NJD population did not exhibit differentiation; when $\mathrm{K}=5$, the NJD population differentiated into two subpopulations: a northwestern group and a southeastern group. The gene flow between the two subpopulations was determined to be 2.6084, indicating strong genetic exchange between the two subpopulations of NJD. However, there was still some genetic differentiation between the two subpopulations $(\mathrm{Gst}=0.1609)$. After possible causes such as the prevention of gene flow were excluded, the reason may be related to differences in habitats within the population. The NJD nature reserve has numerous islands and reefs with meandering shorelines, headlands, and numerous bays. There are many types of coastal beaches, such as mudflats, gravel beaches, and rocky reefs, and NJD is at the intersection of the Taiwan Warm Current and the Jiangsu and Zhejiang Coastal Currents. The flow system is complex, so the habitat is complex (Xiao, 2007). The species of marine shellfish algae in this area not only are abundant but also have characteristics beneficial to temperate zones and tropical zones. Moreover, an obvious regional "fracture distribution" phenomenon is occurring. It is rare that three species with characteristics beneficial to different climate zones (i.e., tropical, subtropical and temperate zones) coexist in the NJD sea area at the same time; for example, typical tropical species such as Oliva emicator can survive in the NJD above $27^{\circ} \mathrm{N}$, which is sufficient to demonstrate the particularity of the NJD habitat (Xiao, 2007). The two subpopulations are separately located in the northwestern and southeastern regions of NJD, and may exhibit some genetic differentiation because of habitat differences. However, our current evidence is insufficient, and additional research is needed.

In the comparison of the genetic diversity index of 22 endemic plant species on the Canary Islands, the average genetic diversity index of island species with relatively large populations (number of individuals $>2500 ; \mathrm{H}=0.1460$ ) was significantly greater than that of island species with relatively small populations (number of individuals $<100 ; \mathrm{H}=0.0970$ ) (Francisco-Ortega et al., 2000). The average diversity index of each population of E. macrophylla was (from large to small) NJD (0.1580)>DRS (0.1290)>DGD (0.1222)>LS (0.1208)>LGD (0.0446), with an average value of 0.1149 . The average genetic diversity index of the NJD population is much greater than that of the LGD population. The values of the other three populations are relatively similar. The NJD population is the largest, the DRS, DGD, and LS populations are similar in size, and the LGD population is declining. Human disturbances such as excessive logging, habitat destruction, and the introduction of exotic species are considered to be the main causes endangering island species (Atkinson, 1989; Frankham, 1997; Raven, 1998), which are manifested mainly as effective population decline, increased frequencies of inbreeding, loss of genetic diversity, decline in survival competitiveness, etc. (Ferson \& Burgman, 1995; Frankham, 1997; Mengens, 1998). NJD is far from mainland China, is relatively closed, and experiences relatively limited exchange with the mainland, so there is little anthropogenic damage. Moreover, the island area is large, and the genetic background is complex, so the island presents high genetic diversity and a large population. LGD is a famous tourist destination in China, and the coastline is developing rapidly. Moreover, LGD has a small area, and its populations have

Peer) reviewing PDF | (2019:06:38915:6:3:NEW 21 Dec 2019) 
377 similar genetic backgrounds and a single habitat; as such, loss of genetic diversity and 378 populations declines have occurred.

379

380

381

382

383

384

385

386

387

388

389

390

391

392

393

394

395

396

397

398

399

400

401

402

403

404

405

406

407

408

409

410

411

412

\section{References}

\section{Conclusions} methods.

\section{Conservation of E. macrophylla diversity}

Am in situ conservation method was proposed because the conservation of sufficient natural population numbers and sizes to prevent a reduction in genetic diversity is urgently needed. The best strategy for in situ conservation of genetic diversity during an endemic is the preservation of natural habitat (Francisco-Ortega et al., 2000). In this study, the NJD population displayed relatively high genetic diversity and should, therefore, be a priority for in situ conservation. The LGD population had the lowest genetic diversity and the smallest population size; the site of this population should be protected as the most urgent site. Furthermore, natural protection areas should be established to conserve and restore the habitat and populations, the awareness of local residents and tourism management personnel should be heightened, and the populations should be increased by artificial cultivation and subsequent management; for example, seeds collected from other populations could be sown, branches could be collected for cuttings, gene barriers could be broken by appropriate species regression, and the genetic diversity of populations could be increased. Moreover, to achieve effective conservation of germplasm resources, efforts are needed to carefully plan and construct pollen banks and gene banks for E. macrophylla.

The present study is the first genetic investigation of Elaeagnus macrophylla using conserved DNA-derived polymorphism markers to investigate the distribution and genetic variation. The results showed that conserved DNA-derived polymorphism markers can be effectively used to study the genetic diversity of Elaeagnus macrophylla populations and revealed that Elaeagnus macrophylla populations have low genetic diversity and high genetic differentiation. The low levels of gene flow between populations are the main cause of the high levels of genetic differentiation. On the basis of these findings, some conservation measures for Elaeagnus macrophylla are proposed.

\section{Acknowledgments}

We thank Qing Zhang of Shandong Agricultural University for assistance with the experimental 
415 Andersen JR, Lübberstedt T. 2003. Functional markers in plants. Trends Plant Sci 8: 554-560.

416 DOI: $10.1016 /$ j.tplants.2003.09.010.

417

418 Atkinson I. 1989. Extinction on islands. In Western D. and Pearl M. eds. Conservation for the

419 twenty-first century. Oxford: Oxford University Press.

420

421

Angélique Q, Debussche M. 2000. Seed dispersal and germination patterns in a rare

422 Mediterranean island endemic (Anchusacrispa Viv, Boraginaceae). Acta Oecologica 21 (6): 303-

423

313. DOI: $10.1016 / \mathrm{s} 1146-609 x(00) 01089-4$.

424

425

426

427

Carlos J, Emerson BC, Oromi P. 2000. Colonization and diversification: towards a phylogeog raphics synthesis for the Canary Islands. Trends in Ecology \& Evolution 15(3): 104-109.

DOI: 10.1016/S0960-0779(01)00213-2.

428

429

Chinese Flora Editorial Board of the Chinese Academy of Sciences. 1983. Chinese Flora.

430

Beijing: Science Press, Volume 52(2) : 015.

431

432

433

434

435

436

437

Chung MG, Chung MY, Oh GS, Epperson BK. 2002. Spatial genetic structure in a Neolitsea sericea population (Lauraceae). Heredity 85: 490. DOI: 10.1046/j.1365-2540.2000.00781.x.

Collard BCY, Mackill DJ. 2009. Conserved DNA-derived polymorphism (CDDP): a simple and novel method for generating DNA markers in plants. Plant Molecular Bioloty Reporter 27: 558-562. DOI: 10.1007/s11105-009-0118-z.

438

439

Doyle JJ, Doyle JL. 1987. A rapid DNA isolation procedure for small quantities of fresh leaf

440 tissue. Phytoch Bull 19: 11-15.

441

442

Emerson BC. 2002. Evolution on oceanic islands: molecular phylogenetic approaches to

443 understanding pattern and process. Molecular Ecology 11: 951-966.

444

DOI: 10.1046/j.1365-294X.2002.01507.x.

445

446

Evanno G, Regnaut S, Goudet J. 2005. Detecting the number of clusters of individuals using the software STRUCTURE: a simulation study. Molecular Ecology 14: 2611-2620.

448 DOI:10.1111/j.1365-294X.2005.02553.x.

449

450

Fang WX, Xia XY, An LJ, Peng Q. 2016. Genetic Diversity and Clustering Analysis of

451 Blueberry Resources by CDDP Markers. Chinese Agricultural Science Bulletin 32(28):136-143. DOI:10.11924/j.issn.1000-6850.casb16020078.

453 
454 Ferson S, Burgman MA. 1995. Correlations, dependency bounds, and extinction risks.

455

456

457

458

459

460

461

462

463

464

465

466

467

468

469

470

471

472

473

474

475

476

477

478

479

480

481

482

483

484

485

486

487

488

489

490

491

492

493

Biological Conservation 73: 101-105. DOI: 10.1016/0006-3207(95)90031-4.

Fu LG, Jin JM. 1992. China plant red data book rare and endangered plants vol.1. Sci Press, 558-559. DOI: 10.1016/j.anai.2010.03.006.

Francisco-Ortega J, Santos-Guerra A, Kim SC, Crawford D. 2000. Plant genetic diversity in the Canary Islands: a conservation respective. American Journal of Botany 87(7): 909-919. DOI: $10.2307 / 2656988$.

Frankham R. 1997. Do island populations have less genetic variation than mainland populations? Heredity 78: 311-327. DOI: 10.1038/hdy.1997.46.

Gerber S, Chadoeuf J, Gugerli F, Lascoux M, Buiteveld J, Cottrell J, Dounavi A, Fineschi S, Forrest LL, Fogelqvist J, Goicoechea PG, Jensen JS, Salvini D, Ven-dramin GG, Kremer-A. 2014. High rates of gene flow by pollen and seed in Oak populations across Europe. PLOS ONE 9: 1-16. DOI: 10.1371/journal.pone.0085130.

Grant V. 1991. The evolutionary process: a critical study of evolutionary theory. New York: Columbia University Press. DOI: 10.3366/anh.1993.20.1.143a.

Hamilton MB, Miller JR. 2002. Comparing relative rates of pollen and seed gene flow in the island model using nuclear and organelle measures of population structure. Genetics 162(4): 1897-1909. DOI: 10.1017/S0016672302005906.

Hamrick JL, Nason JD. 1996. Consequences of dispersal in plants. Rhodes OE, Chesser R, Smith M. Spatial and temporal aspects of population processes. Chicago: University of Chicago Press, 203-236.

Hanwick JL, Godt MJW. 1990. Allozyme diversity in plant species. Brown AHD, Clegg MT, Kahler AL, Weir BS (eds). Plant Population Genetics, Breeding and Genetic Resources. Massachusetts: Sinauer: 43-63.

Juan YH. 2018. Study on Genetic Diversity of Camellia japonica Population Based on CDDP Molecular Marker. Shandong Agricultural University.

Kwon JA, Morden CW. 2002. Population genetic structure of two rare tree species (Colubrina oppositifolia and Alphitonia ponderosa, Rhamnaceae) from Hawaiian dry and mesic forests using random amplified polymorphic DNA markers. Molecular Ecology 11: 991-1001.

DOI: 10.1046/j.1365-294X.2002.01497.x. 
494

495

496

497

498

499

500

501

502

503

504

505

506

507

508

509

510

511

512

513

514

515

516

517

518

519

520

521

522

523

524

525

526

527

528

529

530

531

532

533

Leng X, Wang ZS, An SQ, Feng J, Liu YH, Wang GM. 2005. ISSR analysis of genetic diversity of Ilex integra, an insular endemic plant. Biodiversity 13 (06): 546-557.

DOI: 10.3321/j.issn:1005-0094.2005.06.008.

Li T, Guo JE, Zheng CS, Sun X, Sun XZ. 2014. Genetic diversity and construction of fingerprinting of chrysanthemum cultivars by CDDP marker. Journal of Beijing Forestry University 36(4): 94-101. DOI: 10.13332/j.cnki.jbfu.2014.04.018.

Liyuan Jiang, Dekui Zang. 2018. Analysis of genetic relationships in Rosa rugosa using conserved DNA-derived polymorphism markers. Biotechnology \& Biotechnological Equipment 32:1 88-94, DOI: 10.1080/13102818.2017.1407255.

Li YY. 2013. Screening of CDDP Molecular Marker Primers for Tree Peony and Analysis of Its Polymorphism. Journal of Nuclear Agricultural Sciences 27(08): 1099-1105.

DOI: $10.11869 / \mathrm{hnxb.2013.08.1099.}$

Manel S, Schwartz MK, Luikart G, Taberlet P. 2003. Landscape genetics: combined landscape ecology and population genetics. Trends in Ecology and Evolution 18 (4): 189-197. DOI: $10.1016 / \mathrm{s} 0169-5347(03) 00008-9$.

Manson RH, Stiles EW. 1998. Links between Microhabitat Preferences and Seed Predation by Small Mammals in Old Fields. Oikos 82: 37-50. DOI: $10.2307 / 3546915$.

Mengens E. 1998. Evaluating extinction risks in plant populations. In: Fiedler PL, Kareiva PM eds. Conservation biology: for the coming decade (2nd ed.). New York: Chapman and Hall.

DOI: 10.1007/978-1-4757-2880-4_3.

Nei M. 1978. Estimation of average heterozygosity and genetic distance from a small number of individuals. Genetics 89(3): 583-590. DOI: 10.0000/PMID17248844.

Ouborg NJ, Piquot Y, Groenendael JMV. 1999. Population genetics, molecular markers and the study of dispersal in plants. Journal of Ecology 87: 551-568.

DOI: 10.1046/j.1365-2745.1999.00389.x.

Petit RJ, Aguinagalde I, Beaulieu JL, Bittkau, Brewer S, Cheddadi R, Ennos R, Fineschi S, Grivet D, Lascoux M, Mohanty A, Müller-Starck G, Demesure-Musch B, Palmé A, Martí JP, Rendell S, Vendramin GG. 2003. Glacial refugia : Hotspots but not melting pots of genetic diversity. Science 300: 1563-1565. DOI: 10.1126/science.1083264.

Peer) reviewing PDF | (2019:06:38915:6:3:NEW 21 Dec 2019) 
534

535

536

537

538

539

540

541

542

543

544

545

546

547

548

549

550

551

552

553

554

555

556

557

558

559

560

561

562

563

564

565

566

567

568

569

570

571

572

573

Poczai P, Varga I, Bell NE, Hyvönen J. 2011. Genetic diversity assessment of bittersweet (Solanum dulcamara, Solanaceae) germplasm using conserved DNA-derived polymorphism and intron-targeting markers. Ann Appl Biol 159: 141-153.

DOI: $10.1111 / \mathrm{j} .1744-7348.2011 .00482 . x$.

Pritchard JK, Stephens M, Donnelly P. 2000. Inference of population structure using multilocus genotypes data. Genetics 155: 945-959.

Qin YY, Zhang QD, Yan GQ. 2006. RAPD Analysis of Genetic Diversity in Populations of the Endangered Plant of Elaeagnus mollis Diels. Molecular Plant Breeding, (S2): 31-36.

Raven PH. 1998. Plant conservation in a changing world. Aliso, 16 : 121-126.

DOI: 10.5642/aliso.19971602.07.

Reid WV, Miller KR. 1989. Keeping Options Alive : The Scientific Basis for Conserving Biodiversity. Washingt on DC : World Resources Institute.

Rohl FJ. 1994. NTSYS-PC. Version 2. 10, New York : Appllied Biostatistics Inc.

Sahuquillo E, Lumaret R. 1995. Variation in the subtropical group Dactylis glomerata L.-1. Evidence from allozyme polymorphism. Biochemical Systematics and Ecology 23: 407-418. DOI: 10.1016/0305-1978(95)00020-u.

Starkin M. 1987. Gene flow and geographic structure of natural populations. Science 236: 787792. DOI: $10.1126 /$ science. 3576198 .

Wang ZS, An SQ, Leng X, Ding FM, Zheng JW, Chen L. 2004. Population genetic diversity of the insular plant Neolitsea sericea based on random amplified polymorphic DNA (RAPD). Acta ecologica sinica, (03): 414-422. DOI: 10.3321/j.issn:1000-0933.2004.03.004.

Weller SG, Sakai AK, Straub C. 1996. Allo zyme Diversity and genetic identity in Schiedea and Alsinidendron ( Caryophyllaceae: Alsinoideae) in the Hawaiian Islands. Evolution 50: 2334. DOI: $10.2307 / 2410777$.

Wolf A , Harrison SP. 2001. Effects of habit at size and pat chisolation on reproductive success of the Serpentine Morning Glory. Conservation Biology 15: 111-121. DOI: 10.2307/2641650.

Wright S. 1965. The interpretation of population structure by F-statistics with special regard to systems of mating. Evolution 19: 395-420. DOI: 10.2307/2406450. 
574

575

576

577

578

579

580

581

582

583

584

585

586

587

588

589

590

591

592

593

594

595

596

597

598

599
Xiao JM. 2007. Ecosystem Assessment of Nanji island Based on PSR Model. Xiamen university. DOI: $10.7666 /$ d.y1344641.

Yeh FC, Yang RC, Boyle T. 1999. POPGENE Version 1.31. Microsoft window-based freeware for population genetic analysis. University of Alberta and Centre forInternational Forestry Research.

Zang DK. 2012. Landscape Dendrology (2nd ed.). Beijing: China building industry press, 298299.

Zang DK, 2016. Rare and endangered plants in Shandong. Beijing: China Forestry Publishing House. 126-127.

Zhang DY, Jiang XH. 1999. Progress in studies of genetic diversity and conservation biology of endangered plant species. Chinese Biodiversity 7(1): 31-37.

DOI: 10.3321/j.issn:1005-0094.1999.01.006.

Zhang F, Wang ZS, An SQ, Leng X, Feng J, Wei N, Chen SN. 2007. Effect of excursion of plant seeds floating on genetic differentiation of seaside species Eurya emarginated Makine around the Zhoushan Archipelago. Ocean science (05): 25-31.

DOI: 10.3969/j.issn.1000-3096.2007.05.006.

Zhang XL, Xu JW, Shen HL, Huang J, Zhang P. 2010. Animal predation and dispersal of Sorbus pohuashanensis fruits and seeds. Chinese Journal of Applied Ecology Oct. 21(10): 26772683. DOI: $10.13287 /$ j.1001-9332.2010.0358. 
Figure 1

Geographical location of the 7 sampling points (including Putuo Island and Lingshan Island where only one sample was collected) of E. macrophylla in China

Show the geographical location of 7 sampling points by zooming in on the four areas A, B, C, and D.
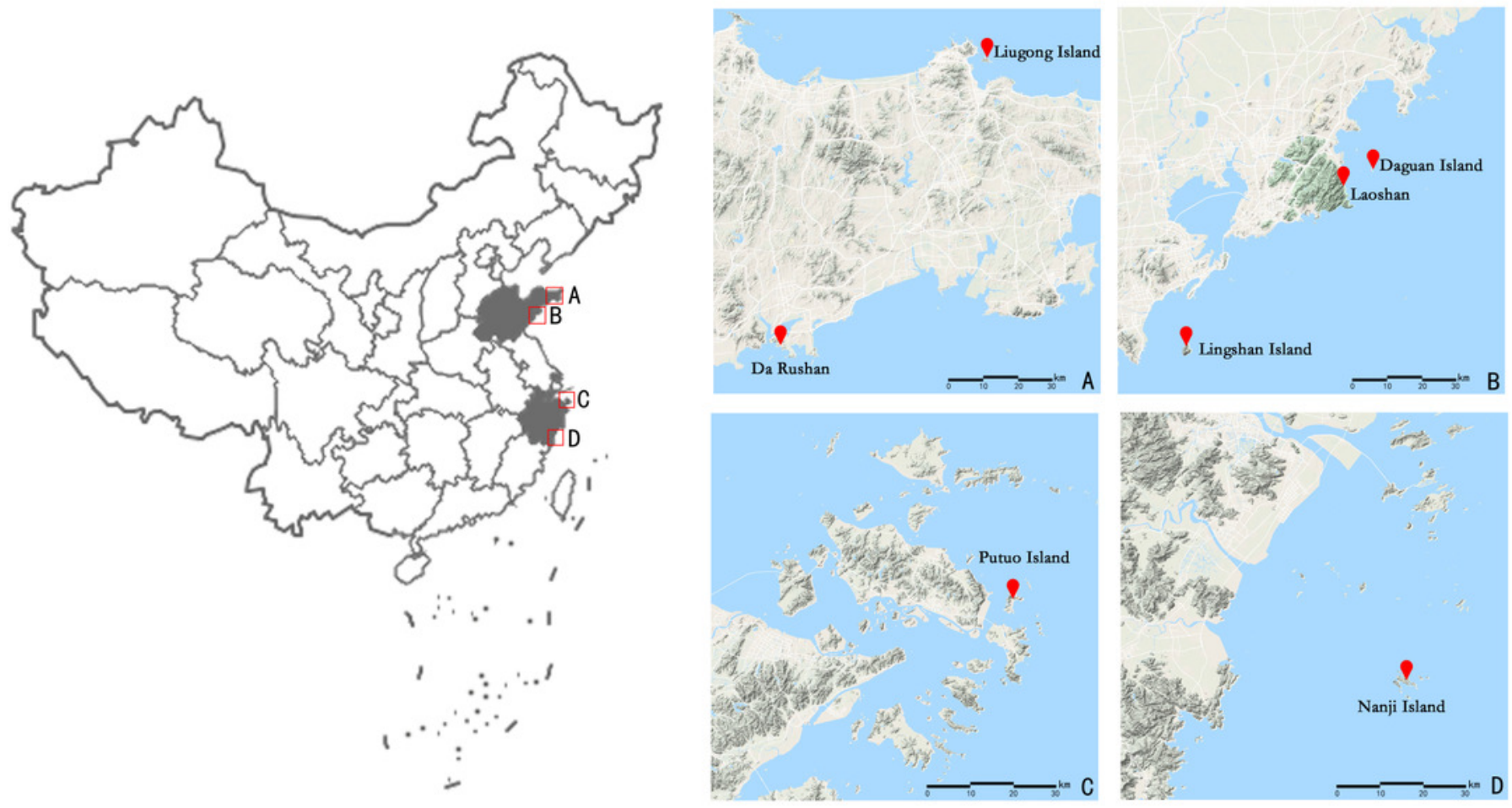


\section{Figure 2}

Amplification results for MYB1 in the Liugong Island population and the Da Rushan population.

Amplification results for MYB1 in the Liugong Island population (1-8) and the Da Rushan population (9-20), Marker=DL2000.

$\begin{array}{lllllllllllllllllllll}\text { M } & 1 & 2 & 3 & 4 & 5 & 6 & 7 & 8 & 9 & 10 & 11 & 12 & 13 & 14 & 15 & 16 & 17 & 18 & 19 & 20\end{array}$

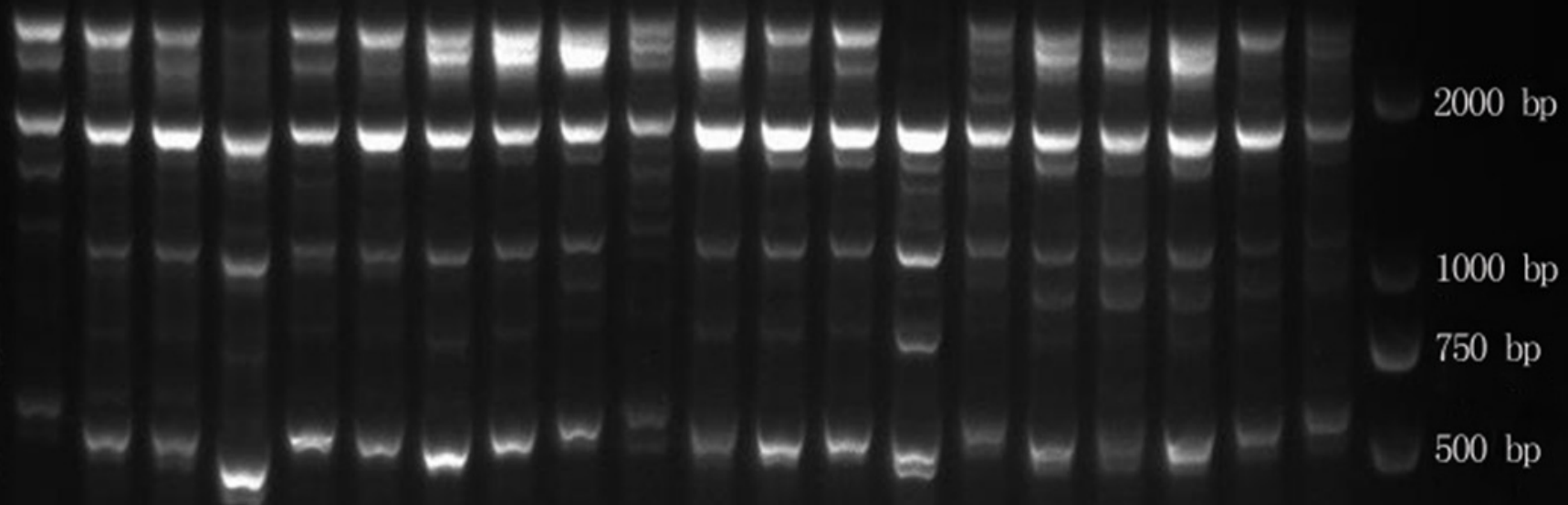


Figure 3

Figure 3 UPGMA cluster analysis of genetic similarity of 5 populations.

UPGMA cluster analysis of genetic similarity of 5 populations: LGD, DRS, NJD, LS, DGD.

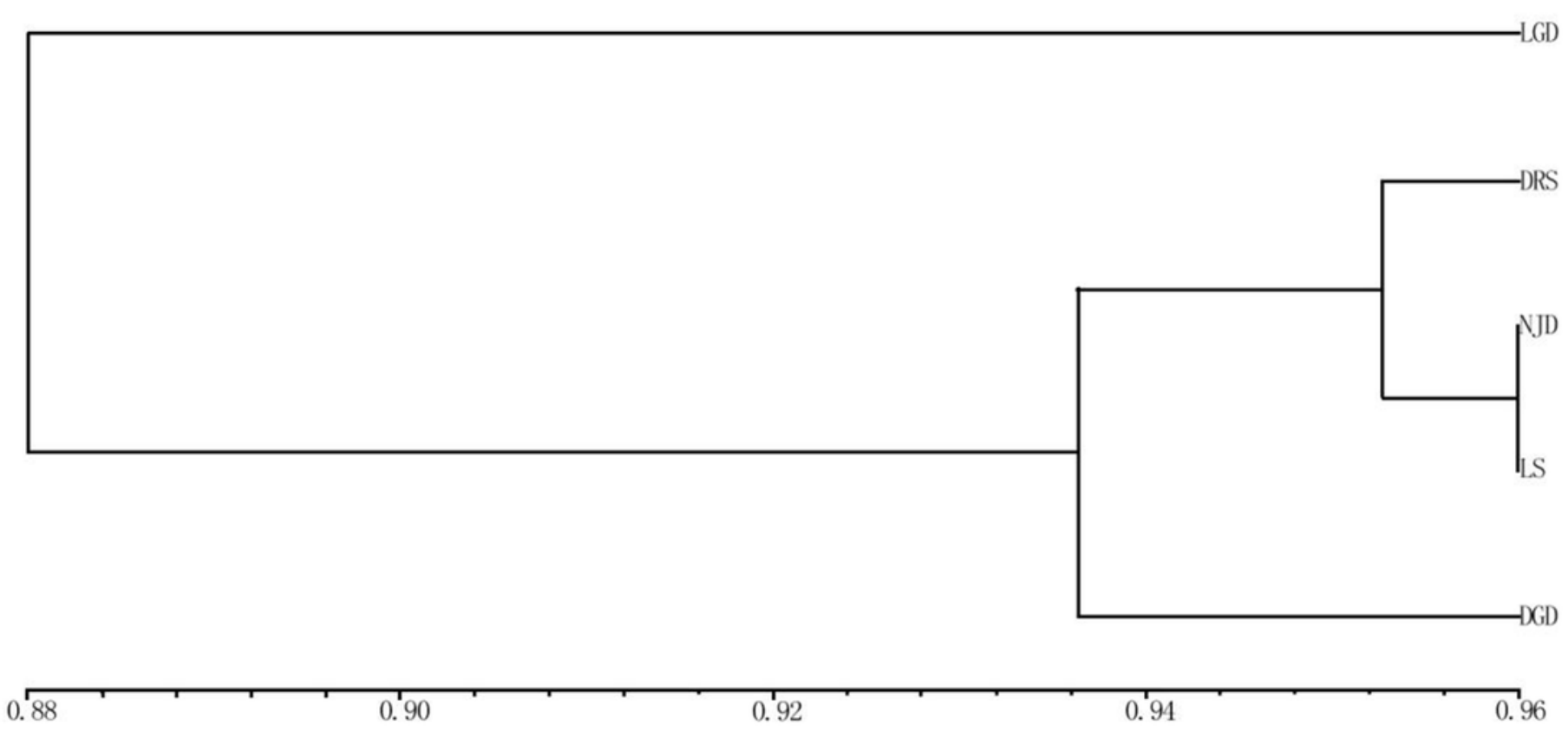


Figure 4

UPGMA cluster analysis of 102 samples of E. macrophylla

LGD(1-8),DRS(9-28), NJD(29-61),PTD(62),LSD(63),LS(64-76), DGD(77-102). 

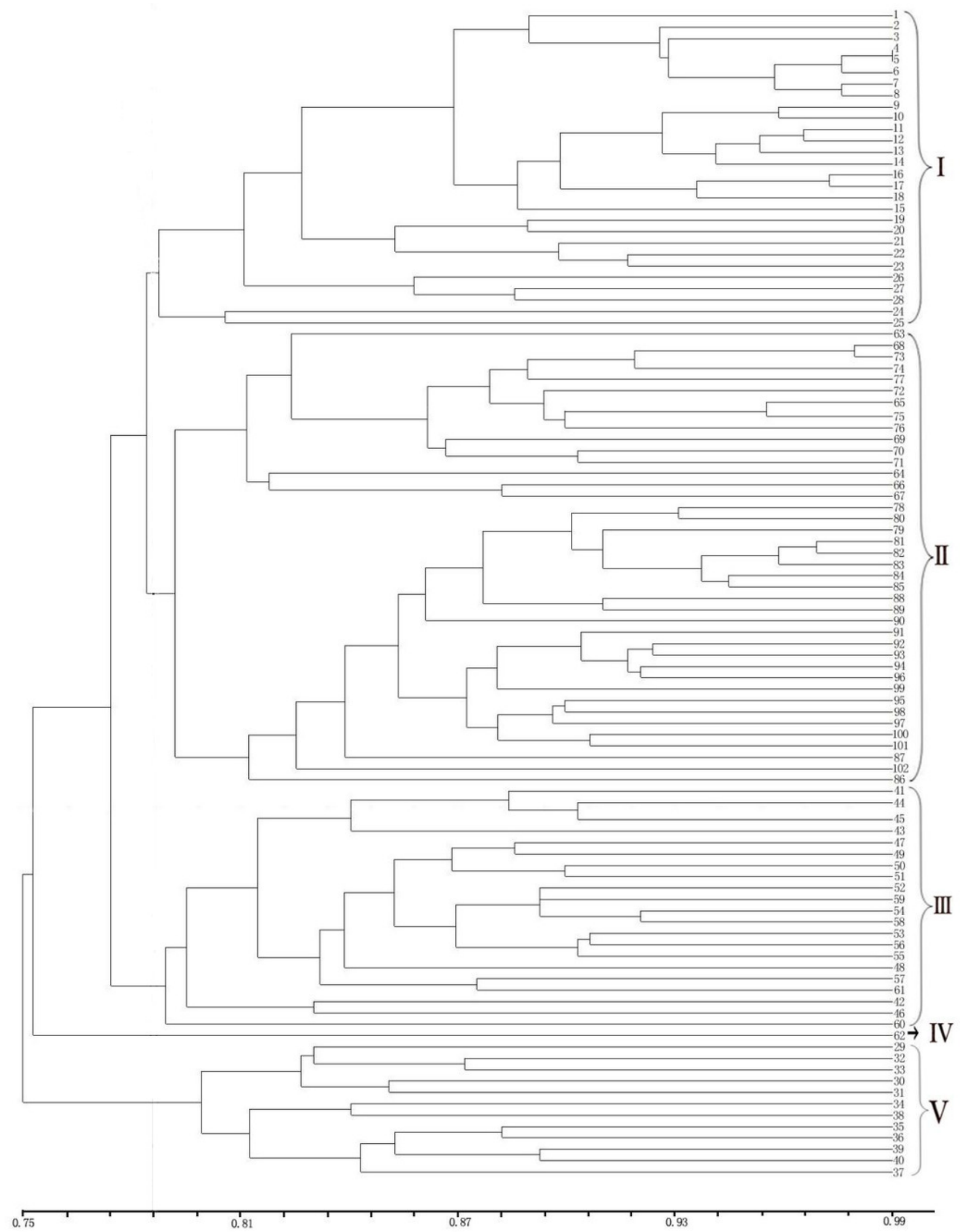
Figure 5

Population structure analysis and Delta-K values
A: Delta-K values
B:Population structure analysis, $\mathrm{K}=3$
C:Population structure analysis, $\mathrm{K}=5$. 

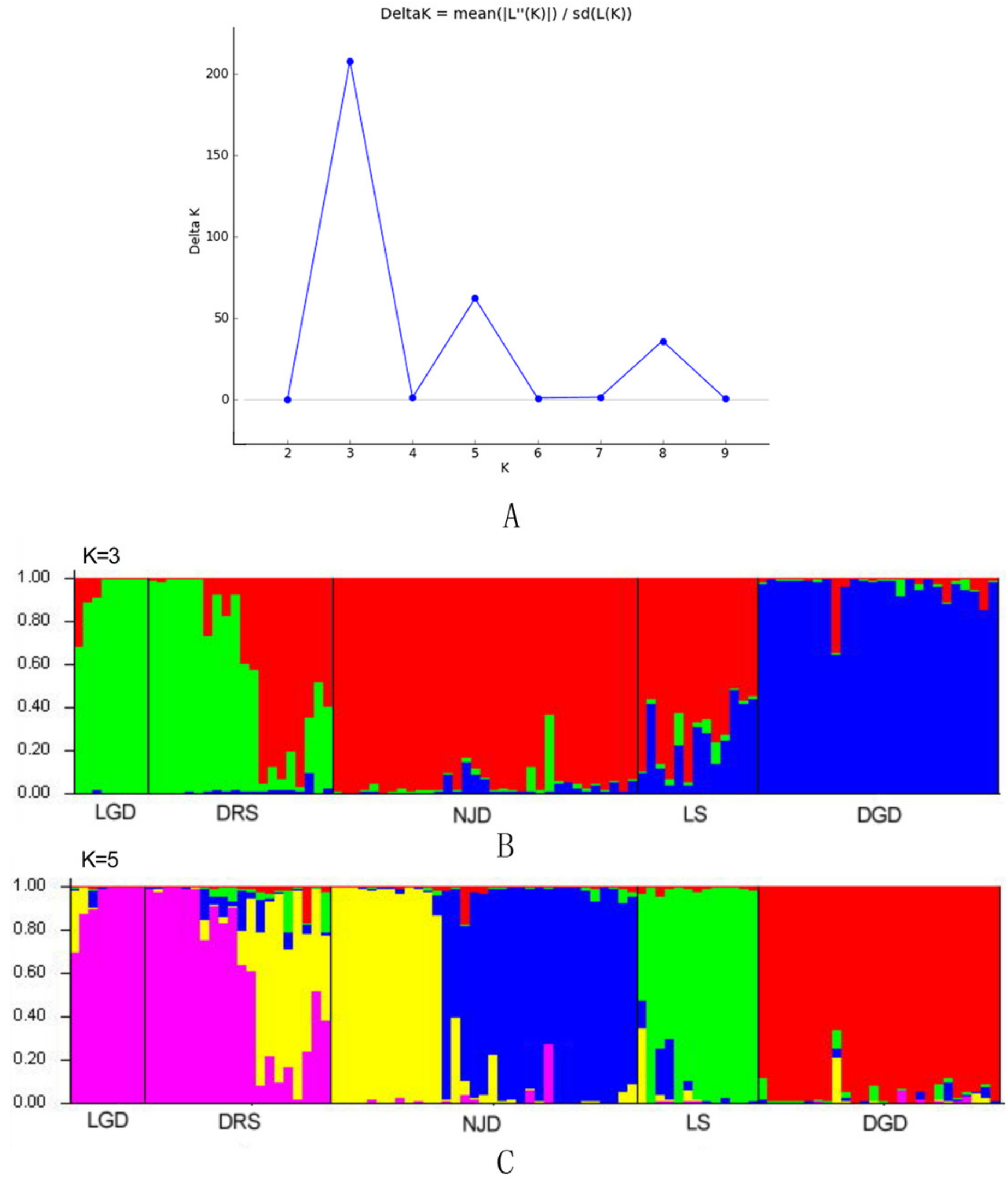


\section{Table $\mathbf{1}$ (on next page)}

Table 1 Sampling information for E. macrophylla

The table shows information such as population name, abbreviation, geographic location, latitude and longitude, and altitude. 
Table 1 Sampling information for E. macrophylla

\begin{tabular}{|c|c|c|c|c|c|}
\hline Population & $\begin{array}{l}\text { Population } \\
\text { abbreviation }\end{array}$ & Number & Locality & Geographical location & $\begin{array}{l}\text { Altitude } \\
\text { (meters) }\end{array}$ \\
\hline Liugong Island & LGD & 8 & $\begin{array}{l}\text { Weihai Bay, Weihai city, } \\
\text { Shandong Province }\end{array}$ & $37^{\circ} 30^{\prime} \mathrm{N}, 122^{\circ} 10^{\prime} \mathrm{E}$ & 22 \\
\hline Da Rushan & DRS & 20 & $\begin{array}{c}\text { Rushan city, Weihai city, } \\
\text { Shandong Province }\end{array}$ & $36^{\circ} 45^{\prime} \mathrm{N}, 121^{\circ} 30^{\prime} \mathrm{E}$ & 5.2 \\
\hline Lingshan Island & LSD & 1 & $\begin{array}{l}\text { Huangdao District, Qingdao } \\
\text { city, Shandong Province }\end{array}$ & $36^{\circ} 27^{\prime} \mathrm{N}, 121^{\circ} 58^{\prime} \mathrm{E}$ & 20 \\
\hline Daguan Island & DGD & 26 & $\begin{array}{l}\text { Laoshan District, Qingdao } \\
\text { city, Shandong Province }\end{array}$ & $36^{\circ} 13^{\prime} \mathrm{N}, 120^{\circ} 46^{\prime} \mathrm{E}$ & 11 \\
\hline Laoshan & LS & 13 & $\begin{array}{l}\text { Laoshan District, Qingdao } \\
\text { city, Shandong Province }\end{array}$ & $36^{\circ} 7^{\prime} \mathrm{N}, 120^{\circ} 39^{\prime} \mathrm{E}$ & 20 \\
\hline Putuo Island & PTD & 1 & $\begin{array}{l}\text { Zhoushan Islands, Zhoushan } \\
\text { city, Zhejiang Province }\end{array}$ & $30^{\circ} 0^{\prime} \mathrm{N}, 122^{\circ} 24^{\prime} \mathrm{E}$ & 96 \\
\hline Nanji Island & NJD & 33 & $\begin{array}{c}\text { Pingyang County, Wenzhou } \\
\text { city, Zhejiang Province }\end{array}$ & $27^{\circ} 28^{\prime} \mathrm{N}, 121^{\circ} 3^{\prime} \mathrm{E}$ & 42 \\
\hline
\end{tabular}

2 


\section{Table 2 (on next page)}

Table 2 Site information for 15 CDDP markers and genetic diversity parameters at each locus of $E$. macrophylla.

Table contains inforations such as primer code, primer names, sequence, annealingTemperature, number of bands recorded, number of polymorphic bands and the percentage of polymorphism. 
1

2

\begin{tabular}{|c|c|c|c|c|c|c|}
\hline $\begin{array}{l}\text { Primer } \\
\text { code }\end{array}$ & $\begin{array}{l}\text { Primer } \\
\text { name }\end{array}$ & Sequence $\left(5^{\prime}-3^{\prime}\right)$ & $\begin{array}{c}\text { Annealing } \\
\text { Temperature }\end{array}$ & $\begin{array}{l}\text { Number } \\
\text { of bands } \\
\text { recorded }\end{array}$ & $\begin{array}{c}\text { Number of } \\
\text { polymorphic } \\
\text { bands }\end{array}$ & $\begin{array}{c}\text { The percentage } \\
\text { of } \\
\text { polymorphism/ } \\
\%\end{array}$ \\
\hline Pr1 & WRKY-F1 & TGGCGSAAGTACGGCCAG & 50 & 21 & 21 & 100 \\
\hline $\operatorname{Pr} 2$ & WRKY-R1 & GTGGTTGTGCTTGCC & 52 & 30 & 30 & 100 \\
\hline $\operatorname{Pr} 3$ & WRKY-R3 & CCGCTCGTGTGSACG & 50 & 21 & 25 & 100 \\
\hline $\operatorname{Pr} 4$ & MYB1 & GGCAAGGGCTGCCGC & 50 & 19 & 19 & 100 \\
\hline $\operatorname{Pr} 5$ & MYB2 & GGCAAGGGCTGCCGG & 50 & 13 & 13 & 100 \\
\hline Pr6 & ERF1 & CACTACCGCGGSCTSCG & 50 & 30 & 30 & 100 \\
\hline $\operatorname{Pr} 7$ & ERF2 & GCSGAGATCCGSGACCC & 50 & 11 & 11 & 100 \\
\hline $\operatorname{Pr} 8$ & ERF3 & TGGCTSGGCACSTTCGA & 50 & 11 & 11 & 100 \\
\hline $\operatorname{Pr} 9$ & KNOX-1 & AAGGGSAAGCTSCCSAAG & 50 & 21 & 21 & 100 \\
\hline $\operatorname{Pr} 10$ & KNOX-2 & CACTGGTGGGAGCTSCAC & 50 & 19 & 19 & 100 \\
\hline $\operatorname{Pr} 11$ & KNOX-3 & AAGCGSCACTGGAAGCC & 50 & 15 & 15 & 100 \\
\hline $\operatorname{Pr} 12$ & MADS-1 & ATGGGCCGSGGCAAGGTGC & 50 & 14 & 14 & 100 \\
\hline $\operatorname{Pr} 13$ & MADS-4 & CTSTGCGACCGSGAGGTG & 50 & 28 & 28 & 100 \\
\hline $\operatorname{Pr} 14$ & ABP1-1 & ACSCCSATCCACCGC & 50 & 14 & 14 & 100 \\
\hline $\operatorname{Pr} 15$ & ABP1-3 & CACGAGGACCTSCAGG & 50 & 18 & 18 & 100 \\
\hline
\end{tabular}

Table 2 Site information for 15 CDDP markers and genetic diversity parameters at each locus of E. macrophylla 


\section{Table 3(on next page)}

Table 3 Genetic diversity in five populations of E. macrophylla.

The table contains information such as population name, number of samples, $\mathrm{Na}, \mathrm{Ne}, \mathrm{H}, \mathrm{I}$, $\mathrm{PPL}$, and standard deviation in parentheses. 
1

2
Table 3 Genetic diversity in five populations of E. macrophylla (standard deviation in parentheses)

\begin{tabular}{|c|c|c|c|c|c|c|}
\hline $\begin{array}{c}\text { Population } \\
\text { name }\end{array}$ & $\begin{array}{c}\text { Number of } \\
\text { samples }\end{array}$ & $\mathrm{Na}$ & $\mathrm{Ne}$ & $H$ & $I$ & $P P L(\%)$ \\
\hline LGD & 8 & $\begin{array}{c}1.1488 \\
(0.3565)\end{array}$ & $\begin{array}{c}1.0739 \\
(0.2178)\end{array}$ & $\begin{array}{c}0.0446 \\
(0.1210)\end{array}$ & $\begin{array}{c}0.0690 \\
(0.1785)\end{array}$ & 14.88 \\
\hline DRS & 20 & $\begin{array}{c}1.5398 \\
(0.4993)\end{array}$ & $\begin{array}{c}1.2002 \\
(0.2850)\end{array}$ & $\begin{array}{c}0.1290 \\
(0.1622)\end{array}$ & $\begin{array}{c}0.2070 \\
(0.2381)\end{array}$ & 53.98 \\
\hline NJD & 33 & $\begin{array}{c}1.8028 \\
(0.3986)\end{array}$ & $\begin{array}{c}1.2410 \\
(0.2931)\end{array}$ & $\begin{array}{c}0.1580 \\
(0.1566)\end{array}$ & $\begin{array}{c}0.2613 \\
(0.2198)\end{array}$ & 80.28 \\
\hline LS & 13 & $\begin{array}{c}1.4998 \\
(0.4983)\end{array}$ & $\begin{array}{c}1.1941 \\
(0.3020)\end{array}$ & $\begin{array}{c}0.1208 \\
(0.1680)\end{array}$ & $\begin{array}{c}0.1898 \\
(0.2458)\end{array}$ & 50.52 \\
\hline DGD & 26 & $\begin{array}{c}1.5502 \\
(0.4983)\end{array}$ & $\begin{array}{c}1.1912 \\
(0.2878)\end{array}$ & $\begin{array}{c}0.1222 \\
(0.1615)\end{array}$ & $\begin{array}{c}0.1968 \\
(0.2355)\end{array}$ & 44.98 \\
\hline Mean & 20 & 1.5083 & 1.1801 & 0.1149 & 0.1848 & 48.928 \\
\hline Species level & 100 & $\begin{array}{c}1.9654 \\
(0.1831)\end{array}$ & $\begin{array}{c}1.2601 \\
(0.2845)\end{array}$ & $\begin{array}{c}0.1724 \\
(0.1532)\end{array}$ & $\begin{array}{c}0.2869 \\
(0.2098)\end{array}$ & 96.54 \\
\hline
\end{tabular}

3 Note: The PTD and LSD populations are not include because there was only one sample for each.

4 


\section{Table 4(on next page)}

Table 4 Nei's genetic identity (above diagonal) and genetic distance (below diagonal) for five populations.

Liugong Island (LGD), Da Rushan (DRS), Nanji Island (NJD), Laoshan (LS), Daguan Island (DGD). 
1

2

Table 4 Nei's genetic identity (above diagonal) and genetic distance (below diagonal) for five populations

\begin{tabular}{cccccc}
\hline Population & LGD & DRS & NJD & LS & DGD \\
\hline LGD & $* * * *$ & 0.9253 & 0.8656 & 0.8730 & 0.8697 \\
DRS & 0.0776 & $* * * *$ & 0.9588 & 0.9569 & 0.9431 \\
NJD & 0.1443 & 0.0421 & $* * * *$ & 0.9522 & 0.9391 \\
LS & 0.1358 & 0.0440 & 0.0490 & $* * * *$ & 0.9427 \\
DGD & 0.1396 & 0.0585 & 0.0628 & 0.0590 & $* * * *$ \\
\hline
\end{tabular}

3 